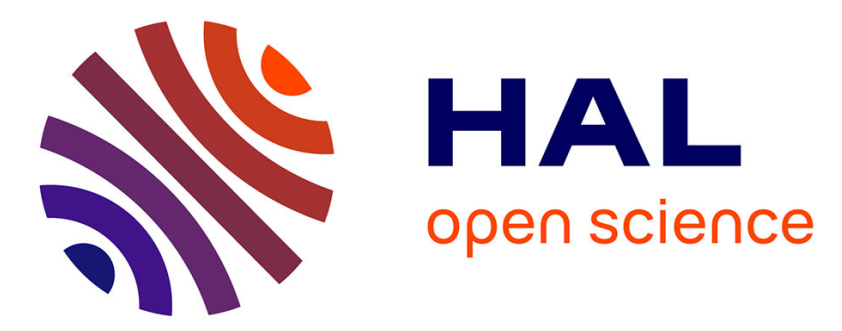

\title{
How Food Companies Manage Their Innovation Process: A Multinational Food Company Point of View
}

\author{
Claudia Pinna, Monica Rossi, Sergio Terzi
}

\section{To cite this version:}

Claudia Pinna, Monica Rossi, Sergio Terzi. How Food Companies Manage Their Innovation Process: A Multinational Food Company Point of View. 15th IFIP International Conference on Product Lifecycle Management (PLM), Jul 2018, Turin, Italy. pp.169-180, 10.1007/978-3-030-01614-2_16 . hal-02075635

\section{HAL Id: hal-02075635 \\ https://hal.inria.fr/hal-02075635}

Submitted on 21 Mar 2019

HAL is a multi-disciplinary open access archive for the deposit and dissemination of scientific research documents, whether they are published or not. The documents may come from teaching and research institutions in France or abroad, or from public or private research centers.
L'archive ouverte pluridisciplinaire HAL, est destinée au dépôt et à la diffusion de documents scientifiques de niveau recherche, publiés ou non, émanant des établissements d'enseignement et de recherche français ou étrangers, des laboratoires publics ou privés. 


\title{
How food companies manage their innovation process: a multinational food company point of view
}

\author{
Claudia Pinna ${ }^{1}$, Monica Rossi ${ }^{1}$, Sergio Terzi ${ }^{1}$ \\ ${ }^{1}$ Politecnico di Milano, Department of Management, Economics and Industrial \\ Engineering Piazza Leonardo da Vinci, 20133, Milan, Italy \\ claudia.pinna@polimi.it, monica.rossi@polimi.it, \\ sergio.terzi@polimi.it
}

\begin{abstract}
This current research, as a natural consequence of previous findings, focuses on the first phase of the New Food Development (NFD) process. Being this phase the most creative and innovative, it comes naturally to think it is also the most chaotic, very difficult to standardize and to control. At the same time, this phase is considered one of the most important of the overall process, because it adds the most value to the product that is going to be created. Starting from these considerations, the aim of this paper is to enrich the previous study by understanding how food companies could enhance their competitiveness by leveraging on their front-end process, with a special focus on the use of structured approaches for creativity and innovation and on the PLM solution. An important multinational food company has been used as a case study to investigate the above research objectives and to provide a preliminary conceptual framework to model the impact of structured front-end process on the overall NFD success. This study allowed to identify how the FFE food process is structured, the main CSFs and KPIs, as well as which methods and IT tools are used to support the analyzed process. Concerning the latest, a deeper analysis has been done focusing on the PLM solution, understanding how its functionalities are used to support the different FFE process sub-activities. Finally, this work confirms the results identified in the previous study, affirming the lack of adoption that the PLM solution plays in the FFE phase.
\end{abstract}

Keywords: Food Sector, Innovation process, New Food Development, New Product Development, NPD.

\section{Introduction}

Over the last years, the food industry has become increasingly relevant since it represents excellence in the worldwide economy [1]. However, despite the growing importance of this sector, food firms still face many challenges in managing their products and competing in the market. This research starts from the results of previous works, focused on the new product development process - called New Food Development process (NFD) for the food context, being recognized as an added value process for food companies [2], [3]. NFD generates value for the product that they have to introduce to 
the market, contributing consequently to greater success. This is necessary since in a highly competitive market food companies must develop new products valued by consumers. While previous studies from the authors [3]-[7] discuss how multinational food firms could increase their competitiveness in the market and improve their performance by leveraging on the use of the Product Lifecycle Management (PLM) solution to support the NFD process, this current research, as a natural consequence of previous findings, focuses on the first phase of the same process, called 'upfront' or 'Fuzzy FrontEnd' (FFE). Important considerations have emerged from the results of such study. In particular, being the FFE phase the most creative and innovative of the process taken into consideration, it is also the most chaotic, very difficult to standardize and to control. At the same time, this phase is considered one of the most important of the overall process because it adds the most value to the product that is going to be created. The aim of this paper is to understand how food companies could enhance their competitiveness by leveraging on their FFE process - considering the use of structured approaches for creativity and innovation and on the possible tools, with a particular focus on the PLM solution. Therefore, the study focuses on: (i) how the process is structured, (ii) the main tools and methods as well as (iii) the main Critical Success Factors (CSF) and KPIs. This study is part of a wider research project - started in January 2018 and still ongoing - that has the main objective to understand the role of methods and tools on FFE food performances, with a specific focus on the role of the PLM solution. The work was carried out independently, in collaboration with an Italian company which has been used as case study. The company is a historic Italian firm operating in the bakery sector and part of a group that is the owner of several brands. It deals also with production on behalf of third parties and private labels. This collaboration allows to investigate the research objectives and to validate the preliminary conceptual framework and questionnaire developed. The paper starts, in section 2, with a state of the art about methodologies and tools used to support the fuzzy front end process in the food industry. Following, section 3, describes a preliminary empirical research, which defines the research methodology, as well as the meaning and scope of the difference from each part of the questionnaire. In section 4, results of the case study have been presented and developed with the aim to validate the questionnaire. In this section, particular attention has been given to the PLM solution. Finally, session 5 concludes the paper, presenting some thoughts about future research.

\section{State of the art: methodologies and tools for FFE}

The literature review has been conducted with the aim to investigate if there are some scientific studies concerning the use of methodologies and/or tools supporting the FFE process phase. The FFE is the first phase of the NPD process. It begins when an opportunity is first considered worthy of further ideation, exploration, and assessment and it ends when a firm decides to invest in the idea, commit significant resources to its development and launch the project [8]-[10]. Thus, the FFE could be defined as the period between when an opportunity is first considered and when an idea is judged ready for development. The FFE phase, contrary to the development phase, is intrinsically non- 
routine, dynamic and uncertain. The idea-development and subsequent idea-selection stages typically involve ad hoc decisions and ill-defined process [11]. This phase can be further divided in order to better manage it. Griffin (1997), for example, divides the predevelopment phase by the 'concept generation stage', this latter begins when the idea for the product first surfaces, and also by the 'project evaluation stage', which starts when the product strategy and target market have been approved and the project has been given a 'go' to develop specifications [12].

According to Monteiro et al (2010), FFE is an essential phase leading to the success of innovation [13], this is the reason why various software tools have been proposed to support FFE activities. The aforementioned authors conducted a systematic literature review analyzing 1090 articles published between 1997 and 2009. The results obtained show that the use of software tools supporting the FFE process can generate many benefits, among which to: speed up the FFE, reduce costs, increase collaboration, improve decision quality and knowledge management, reduce risks, and enhance overall creativity [13]. Therefore, companies may support their FFE using different tools, methods, and techniques [14]. Thus, the use of tools, methods, and techniques that support the FFE of innovation seems to have a positive influence on innovation performance. Starting from these considerations, the main aim of the next sections is to understand with a practical study which tools and methodologies are used to support the FFE phase by food companies.

\section{Preliminary empirical research}

\subsection{Theoretical framework and research questions}

To achieve the research aim, a methodology based on 6 different activities have been proposed. These activities are focused on the identification of:

1. the main activities characterizing the FFE food process,

2. the main information characterizing each phase of the FFE food process,

3. the methods used to support the FFE food process,

4. the tools used to support the FFE food process,

5. the actors involved in the FFE food process,

6. the main KPIs and CSFs used to measure the FFE food process.

To develop these actions, a questionnaire was developed. Figure 1 shows the theoretical framework and the logic sequence used to develop the different sections of the questionnaire. 
Fig. 1. Research framework

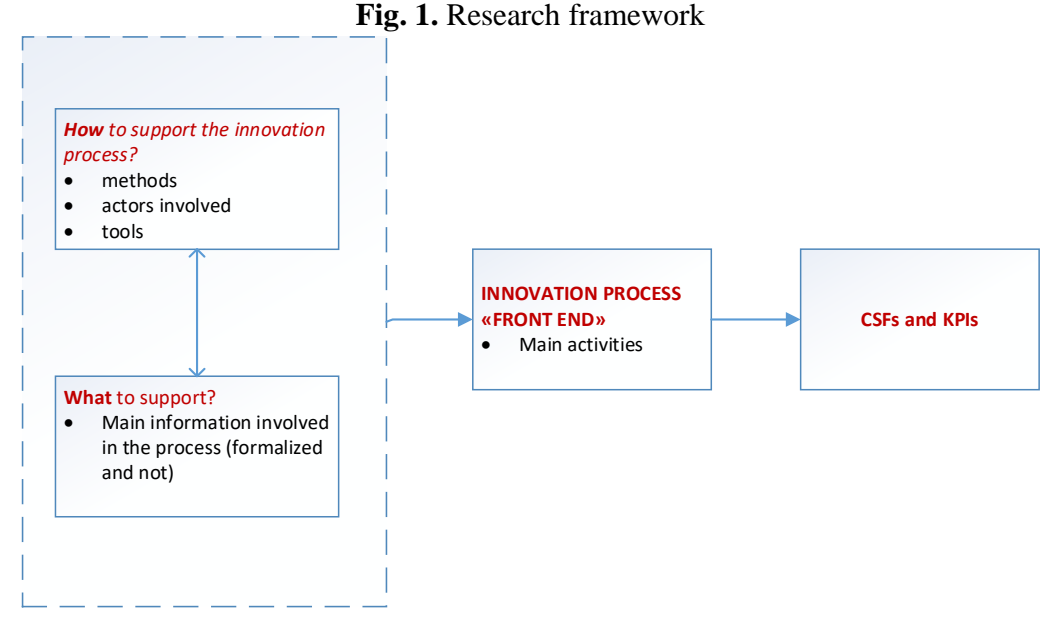

\subsection{Methodology - research strategy}

In this work, Case Study [15] has been utilized as a research strategy.

Questionnaires were used as a research tool. In January 2018, it was tested and validated through a Pilot Case with the help of an important Italian food company. Company actors who mostly interface with this solution were chosen (R\&D and IT managers). The pilot case questionnaire has been first submitted to the R\&D and IT managers by email and a face to face interview have been developed. A standard protocol was followed and identified to be valid for each case study. Up to now, the paper is structured following the main section of the protocol. Results of this pilot case are presented in the following section.

\section{A first empirical research}

\subsection{Company overview}

The company interviewed is a historic Italian company of bakery products. It mostly produces traditional Italian bakery products such as panettone, pandoro, colomba, and croissants. The group is also the owner of several brands. They also deal with production on behalf of third parties and private label. Accordingly, their products could be essentially divided into three categories, that are: recurring products (those products that are typically sold during the Catholic holidays), pre-recurring products (really tasted products offered before festivities by supermarkets) and dairy products (snacks are their main daily consumption products and specifically the naturally leavened croissants).

\section{Company CSFs and KPIs}

The first section of the questionnaire is dedicated to the company overview. This phase allows understanding the company, and specifically, the sector its belonging to, as well 
as the strategic objectives (CSFs) and the indicators used to measure their achievements (KPIs). Usually, CSFs are used to define key areas of activity and to identify the strategic indicators of the company [8].

In the case of analysis, two main CSFs have been identified: (i) Company growth through geographical expansion and (ii) product quality.

Concerning the indicators used to measure the company performances, two main KPIs are mostly used (i) financial measures, defined as an estimation of the achievement of certain turnover targets linked to the new products, both for the Italian and the international market and (ii) volume measures defined as quantity, number of pieces produced or kilos. At this point, authors decided to focus on one specific category of product and of innovation (incremental innovation), in order to limit the boundaries of this research and obtain more precise results. From that point until the end, the analysis focuses on the daily product category and specifically on the healthy segment products.

\subsection{Company New Food Development process: phases, activities, CSFs and KPIs}

The second section of the questionnaire allows to better understand how the NFD process is carried out. Starting from results of a previous research [3]-[5], [7], [16], the main phases and activities characterizing the NFD process, reported in Table 1, have been validated. Furthermore, CSFs and KPIs have been identified, with a specific focus on the research boundaries. Results from this section of the questionnaire are shown in the following table:

Table 1. Company NFD phases, activities, CSFs and KPIs.

\begin{tabular}{|c|c|c|c|}
\hline Phases & Activities & CSFs & KPIs \\
\hline \multirow{3}{*}{ FFE or Pre-development } & Concept generation & $\begin{array}{l}\text { - Concept and product ade- } \\
\text { quacy with respect to con- } \\
\text { sumers expectations }\end{array}$ & $\begin{array}{l}\text { - Consumer satisfaction test compared } \\
\text { to some predefined indicators }\end{array}$ \\
\hline & Feasibility analysis & & $\begin{array}{l}\text { - Turnover derived from product inno- } \\
\text { vation }\end{array}$ \\
\hline & Planning & & $\begin{array}{l}\text { - Contribution derived from product } \\
\text { innovation }\end{array}$ \\
\hline \multirow{2}{*}{ Recipe development } & Recipe definition & $\begin{array}{l}\text { The ability of the new prod- } \\
\text { ucts to generate incremental } \\
\text { volumes and turnover }\end{array}$ & - Number of successful ideas \\
\hline & $\begin{array}{l}\text { Recipe test and feasi- } \\
\text { bility }\end{array}$ & & - On time launches \\
\hline \multirow{3}{*}{ Prototyping and test } & $\begin{array}{l}\text { Product internal fea- } \\
\text { sibility }\end{array}$ & & - Compliance with product target cost \\
\hline & $\begin{array}{l}\text { Product external fea- } \\
\text { sibility }\end{array}$ & - Time & - Compliance with project objectives \\
\hline & Prototyping & & \\
\hline \multirow{2}{*}{ Industrialization } & Industrial tests & & \\
\hline & Quality tests & & \\
\hline Production, Launch and & Bulk production & & \\
\hline Commercialization & Timing & & \\
\hline
\end{tabular}


As shown from the table, the main strategical objectives of the company (concerning the NFD process) are customers' expectations, revenue and time.

\subsection{Company Fuzzy front end phase (pre-development)}

The aim of this questionnaire section is to identify the main phases, activities, and subactivities characterizing the company FFE phase. Furthermore, the main CSFs and KPIs have been identified for most FFE sub-activities.

Table 2. Company FFE phases, activities, CSFs and KPIs

\begin{tabular}{|c|c|c|c|c|}
\hline Activities & Sub-activities & $\begin{array}{l}\text { Company } \\
\text { actors }\end{array}$ & CSFs & KPIs \\
\hline $\begin{array}{l}\text { Concept } \\
\text { generation }\end{array}$ & $\begin{array}{l}\text { - Analyze markets } \\
\text { - Consumers usage } \\
\text { and attitudes (U\&A) } \\
\text { - Survey customers } \\
\text { - Generate product } \\
\text { ideas }\end{array}$ & $\begin{array}{l}\text { - Marketing } \\
\text { - Trade market- } \\
\text { ing } \\
\text { - R\&D }\end{array}$ & $\begin{array}{l}\text { - Correspondence between product } \\
\text { and consumer expectation (mostly } \\
\text { related to the presentation and sen- } \\
\text { sory features) }\end{array}$ & $\begin{array}{l}\text { - testing with consumers } \\
\text { - generation of a number of } \\
\text { ideas that succeed the con- } \\
\text { cept test phase } \\
\text { - correspondence between } \\
\text { generated ideas and company } \\
\text { general objectives }\end{array}$ \\
\hline $\begin{array}{l}\text { Feasibility } \\
\text { analysis }\end{array}$ & $\begin{array}{l}\text { - Technical, legal and } \\
\text { regulatory feasibility }\end{array}$ & $\begin{array}{l}\text { - Marketing } \\
\text { - R\&D } \\
\text { - Finance } \\
\text { - Sales } \\
\text { - Operations } \\
\text { - Quality } \\
\text { - Legal }\end{array}$ & $\begin{array}{l}\text { - the possibility of a product with } \\
\text { certain sensory characteristics, } \\
\text { with an extremely limited number } \\
\text { of ingredients and without adding } \\
\text { ingredients that prolong the shelf- } \\
\text { life } \\
\text { - trade-off good product (few in- } \\
\text { gredients and natural) and eco- } \\
\text { nomic competitiveness }\end{array}$ & $\begin{array}{l}\text { - respect of the maximum tar- } \\
\text { get cost } \\
\text { - compliance with current } \\
\text { regulations } \\
\text { - feasibility in "itself" (i.e. Is } \\
\text { it possible to produce a bis- } \\
\text { cuit without additives?) }\end{array}$ \\
\hline Planning & $\begin{array}{l}\text { - Prioritize and ap- } \\
\text { prove ideas } \\
\text { - Define programs } \\
\text { - Create product/pro- } \\
\text { ject/marketing briefs }\end{array}$ & $\begin{array}{l}\text { - Marketing } \\
\text { - R\&D } \\
\text { - Finance } \\
\text { - Sales } \\
\text { - Operations } \\
\text { - Quality }\end{array}$ & & $\begin{array}{l}\text { - Project time } \\
\text { - Project cost }\end{array}$ \\
\hline
\end{tabular}

Company FFE process is characterized by three main activities (concept generation, feasibility analysis, and planning) which in turn are characterized by some sub-activities. Specifically, those sub-activities describe how each activity is carried out.

Analyzing Table 1 and Table 2, some common objectives could be identified, particularly linked to the customer's expectations. However, the FFE food phase puts more emphasis on the sensory aspect and the quality of the product (intended as the use of a low number of natural ingredients).

In this phase of the NFD process, many company actors are involved. The multidisciplinary skills of the team are crucial in this preliminary phase in order to generate a 
product that has to: be aligned with the customer needs (marketing, trade marketing, sales), respect the regulatory compliances (legal), feasible both economically and technically (finance, operations, $R \& D$ ), respect certain quality levels (quality).

\subsection{Information, Tools and Methods supporting company FFE activities}

In this section, the main information characterizing the company FFE activities as well as the main methods and tools supporting these activities are identified and shown in Table 3.

Table 3. Information, Tools and Methods supporting company FFE activities

\begin{tabular}{|c|c|c|c|c|c|}
\hline Sub-activities & Information & Source & Methods & IT Tools & $\begin{array}{l}\text { Methods and } \\
\text { Tools users } \\
\end{array}$ \\
\hline Analyze markets & $\begin{array}{l}\text { - category size } \\
\text { - consumption per capita } \\
\text { - average price } \\
\text { - number of competitors } \\
\text { - market ability to innovate }\end{array}$ & $\begin{array}{l}\text { - data banks (i.e. } \\
\text { nielsen, iri) } \\
\text { - data on innova- } \\
\text { tion (i.e. mintel, } \\
\text { innova) }\end{array}$ & - open innovation & No & $\begin{array}{l}\text { - R\&D } \\
\text { - Marketing }\end{array}$ \\
\hline $\begin{array}{l}\text { Consumers usage } \\
\text { and attitudes } \\
\text { (U\&A) }\end{array}$ & - consumers information & $\begin{array}{l}\text { - research insti- } \\
\text { tutes }\end{array}$ & $\begin{array}{l}\text { - statistical meth- } \\
\text { ods } \\
\text { - data collection }\end{array}$ & No & - Marketing \\
\hline Survey customers & $\begin{array}{l}\text { - shelf space for a certain category } \\
\text { - average price } \\
\text { - \% product sold at a discount }\end{array}$ & $\begin{array}{l}\text { - clients (distribu- } \\
\text { tion chains) }\end{array}$ & No & No & - Trade marketing \\
\hline $\begin{array}{l}\text { Generate product } \\
\text { ideas }\end{array}$ & $\begin{array}{l}\text { - new ingredients } \\
\text { - new technologies } \\
\text { - new packaging }\end{array}$ & - supplier & $\begin{array}{l}\text { - open innovation } \\
\text { - TRIZ } \\
\text { - Design thinking } \\
\text { - workshop with } \\
\text { suppliers }\end{array}$ & $\begin{array}{l}\text { - open innova- } \\
\text { tion portals } \\
\text { - PLM (mostly } \\
\text { as a repository) }\end{array}$ & $\begin{array}{l}\text { - R\&D } \\
\text { - Marketing }\end{array}$ \\
\hline Feasibility analysis & $\begin{array}{l}\text { - possibility to realize the product, } \\
\text { in an economically valid and sus- } \\
\text { tainable way and according to the } \\
\text { law }\end{array}$ & $\begin{array}{l}\text { - technical speci- } \\
\text { fications } \\
\text { - target destina- } \\
\text { tion country laws } \\
\text { and regulations } \\
\text { - details of the in- } \\
\text { come statement, } \\
\text { company finan- } \\
\text { cial data }\end{array}$ & $\begin{array}{l}\text { - there is no de- } \\
\text { veloped method, } \\
\text { it is specific to } \\
\text { each company }\end{array}$ & - PLM & $\begin{array}{l}\text { - R\&D } \\
\text { - Marketing } \\
\text { - Finance } \\
\text { - Sales }\end{array}$ \\
\hline $\begin{array}{l}\text { Prioritize and ap- } \\
\text { prove ideas }\end{array}$ & $\begin{array}{l}\text { - economic considerations } \\
\text { - strategic considerations (ad- } \\
\text { vantages to enter a new market, } \\
\text { new segment, etc) }\end{array}$ & $\begin{array}{l}\text { - company inter- } \\
\text { nal evaluations }\end{array}$ & - Open innovation & No & $\begin{array}{l}\text { - Marketing } \\
\text { - Finance }\end{array}$ \\
\hline
\end{tabular}




\begin{tabular}{|c|c|c|c|c|c|}
\hline Define programs & $\begin{array}{l}\text { - available resources detection } \\
\text { - functions involved } \\
\text { - time allocable for resources } \\
\text { - available budget }\end{array}$ & $\begin{array}{l}\text { - company busi- } \\
\text { ness functions }\end{array}$ & $\begin{array}{l}\text { - project manage- } \\
\text { ment }\end{array}$ & - PLM & $\begin{array}{l}\text { - R\&D } \\
\text { - Marketing }\end{array}$ \\
\hline $\begin{array}{l}\text { Create marketing } \\
\text { briefs }\end{array}$ & $\begin{array}{l}\text { - target cost } \\
\text { - target of time } \\
\text { - target of product } \\
\text { - timing } \\
\text { - resources }\end{array}$ & $\begin{array}{l}\text { - all the previous } \\
\text { phases (formal- } \\
\text { ized summary } \\
\text { previous info) }\end{array}$ & No & - PLM & $\begin{array}{l}\text { - R\&D } \\
\text { - Marketing }\end{array}$ \\
\hline
\end{tabular}

Table 3 highlights which are the main information used to develop each sub-activity of the FFE food process and also the main source used to find that information. Tools and methods supporting each sub-activity have been also identified. In general, the main methods used are open innovation, statistical methods, data collection, TRIZZ, design thinking, the involvement of suppliers (that are considered the main source of innovation) and methods belonging to the project management subject. At the same time, some tools supporting those sub-activities have been identified, and specifically PLM and open innovations portals.

\section{How the PLM solution support the FFE food phase}

Focusing on the use of the PLM solution, functionalities have been identified supporting some the company FFE sub-activities. The sub-activities identified supported by the PLM functionalities are:

- Generate product ideas: PLM is used mostly as a repository. In this phase information coming from previous products already developed by the company, from market analysis focused on the customers' needs as well as from other product life cycle phases are collected and used to support the creation of new ideas; specifically, the main PLM functionalities supporting the information needed by this activity are: product portfolio and program management and specifications management.

- Feasibility analysis: the PLM functionality called regulatory compliance is used to support the regulatory feasibility. This functionality supports tools enabling companies to identify what regulations, policies and obligations are applicable to them. It allows companies to proactively ensure compliance throughout the product life cycle and fully integrate product quality and food safety into the process of developing and managing products;

- Define programs: the PLM functionality called project management is used to support the definition of programs. It supports the project, collecting data and results along all the phases of the project in order to drive the company decisions. This functionality supports the management workflow by automating process workflows, as well as the related ability to create, archive, trace and search documents. Change management workflows direct information (which could be new or changed) to the right people in order to be reviewed and approved, allowing to find mistakes, ensure accuracy and consistency; 
- Create marketing briefs: in this phase, all the information and decision taken along the FFE process phase are formalized in order to generate a common brief that has to be used to support the next product development phases. In this sense, the PLM help to keep the information available, constantly updated and also achievable. This allows facilitating the brief creation, ensuring data availability and reliability. The project management functionality is used to support this activity.

\section{$5 \quad$ Conclusions \& Further Research}

As previously mentioned, this study is part of a wider research project that has the main objective to understand the role of methods and tools on FFE food performances, with a specific focus on the role of the PLM solution. This paper shows the results of a case study analysis, developed with the aid of an Italian company operating in the bakery sector. This study allowed to identify how the FFE food process is structured (activities and sub-activities), the main CSFs and KPIs, as well as which methods and tools are used to support the analyzed process. Concerning the IT tools (open innovation portals and PLM functionalities), a deeper analysis was done for the PLM solution, understanding how its functionalities are used to support the different FFE process sub-activities. This work confirms the previous work results, affirming the lack of adoption that the PLM solution plays in the FFE phase. Specifically, in the previous work [7], Authors stated the interest to understand why PLM functionalities are not implemented in this phase. They also made some hypotheses, that are the following: (i) a lack of understanding of real benefits PLM systems applications might have on those phases, (ii) PLM functionalities might miss to specifically support those phases or simply (iii) implementation of software solutions in such phases are not easy to apply and be sustained on a daily work basis. Analyzing the interview, some considerations have emerged confirming all of these hypotheses. Starting from that, this work defines the main activities and sub-activities characterizing the FFE process. Moreover, special attention has been given to the company strategical objectives. The main company objectives are company growth through geographical expansion and quality. Focusing on the NFD process, the main objectives identified are customers' expectations, revenue and time. Moving to the specific FFE phase, some commonalities have been found concerning the CSFs, and in detail about the customer's expectations aspect. However, the FFE food phase puts more emphasis on the sensory and quality of the product. Moreover, the main methods used for FFE food have been identified. At the same time, some IT tools supporting those sub-activities have been identified. Particular attention has been given to the PLM functionalities supporting the FFE sub-activities. This choice derived from the fact that, even if the majority of the sub-activities are not supported by any tool, among those supported all use the PLM solution. Therefore, this consideration pushed to further investigate the way the PLM solution support the analyzed process. In this concern, PLM functionalities for FFE sub-activities have been identified. In order to understand how to measure the achievement of the CSFs, many KPIs have been identified. The interview confirmed what found in the literature review, concerning the relation be- 
tween the use of tools and technologies in the FFE process and the related performances. In fact, according to Ester Val-Jauregi and Daniel Justel (2007), the use of tools, methods and techniques that support the FFE of innovation seems to have a positive influence on innovation performance[14]. This statement could be considered true also for the specific food sector. Another important result of this research is related to the company actors involved in the FFE food phase. In fact, the multidisciplinary aspect is considered very important in this context because allow developing a concept aligned with different needs and requirements.

Despite the interviewed company is considered as a big company, it still operates in a very traditional way. From the analysis of the interview, it emerged that they are willing to have a new supporting tool but they are not still ready to introduce it. In fact, this transformation involves first of all the workers that have to deal with it. In order to support this change, some training sessions have to be done in the company allowing the introduction of the mindset needed to support this important company evolution.

Despite the relevance of the research topic, some research limitations have been identified, concerning specifically the fact that only one case study has been developed in this study. The methodology adopted needs further analysis to generalize the results: a quantitative approach with a higher number of food firms adopting methods and tools to support the FFE food phase is necessary. Moreover, this research is explorative in nature, representing the first step toward a complete understanding of the phenomenon analyzed. A quantitative methodology could be developed assess more in detail the impact of the use of methods and tools on FFE food performances.

\section{References}

[1] R. J. Lehmann, R. Reiche, and G. Schiefer, "Future internet and the agri-food sector: State-of-the-art in literature and research,” Comput. Electron. Agric., vol. 89, pp. 158174, 2012.

[2] M. Rossi and S. Terzi, "CLIMB: maturity assessment model for design and engineering processes,” Int. J. Prod. Lifecycle Manag., vol. 10, no. 1, p. 20, 2017.

[3] C. Pinna, L. Plo, V. Robin, P. Girard, and S. Terzi, "An approach to improve implementation of PLM solution in food industry - case study of Poult Group,” Int. J. Prod. Lifecycle Manag., vol. 10, no. 2, pp. 151-170, 2017.

[4] C. Pinna, E. Avolio, R. Bandinelli, S. Terzi, and R. Rinaldi, "Product Development KPIs : a case study analysis in Food and Fashion companies," in XXII Summer School

"Francesco Turco" - Industrial Systems Engineering Product, 2017.

[5] E. D’Avolio, C. Pinna, R. Bandinelli, and S. Terzi, “Analysing Product Development process and PLM features in the Food \& Fashion industries," in IFIP 14th International Conference on Product Lifecycle Management (PLM17), 2017.

[6] C. Pinna, M. Taisch, and S. Terzi, "PLM in the Food Industry: An Explorative Empirical Research in the Italian Market,” in Product Lifecycle Management for Digital Transformation of Industries, R. Harik, L. Rivest, A. Bernard, B. Eynard, and A. Bouras, Eds. Cham: Springer International Publishing, 2016, pp. 238-247.

[7] C. Pinna, F. Galati, M. Rossi, C. Saidy, R. Harik, and S. Terzi, "Effect of product 
lifecycle management on new product development performances: Evidence from the food industry," Comput. Ind., vol. 100, no. August 2017, pp. 184-195, Sep. 2018.

[8] P. G. Smith and D. G. Reinertsen, "Shortening the Product Development Cycle," Res. Manag., vol. 35, no. 3, pp. 44-49, 1992.

[9] R. G. Cooper, Winning at New Products: Accelerating from Idea to Launch, 2nd ed. Addison-Wesley, 1993.

[10] A. Khurana and S. R. Rosenthal, "Towards holistic 'front ends' in new product development,” J. Prod. Innov. Manag., vol. 15, no. 1, pp. 57-74, Jan. 1998.

[11] M. M. Montoya-Weiss and T. M. O’Driscoll, "From experience: applying performance support technology in the fuzzy front end,” J. Prod. Innov. Manag., vol. 17, no. 2, pp. 143-161, Mar. 2000.

[12] A. Griffin, "The Effect of Project and Process Characteristics on Product Development Cycle Time,” J. Mark. Res., vol. 34, no. 1, pp. 24-35, 1997.

[13] C. Monteiro, D. F. Arcoverde, F. Q. B. da Silva, and H. S. Ferreira, "Software support for the Fuzzy Front End stage of the innovation process: a systematic literature review," 2010 IEEE Int. Conf. Manag. Innov. Technol., pp. 426-431, 2010.

[14] E. Val-jauregi and D. Justel, "Use of Tools, Methods and Techniques During the Fuzzy Front End of Innovation: Their Impact on Innovation Performance - a Survey Based Exploratory Study of Companies in the Basque Country -," Innovation, no. August, pp. 1-12, 2007.

[15] R. K. Yin, “Case Study Research . Design and Methods,” SAGE Publications, vol. 26, no. 1. pp. 93-96, 2003.

[16] C. Pinna, M. Taisch, and S. Terzi, "PLM in the Food Industry : an Explorative Empirical Research in the Italian Market Introduction,” in 13th IFIP International Conference on Product Lifecycle Management (PLM16), 2016, no. iv, pp. 238-247. 